\title{
SOLID CaCO3 FORMATION IN WATERS OF CIRCULATING COOLING SYSTEMS OF POWER PLANTS UNDER THE CONDITIONS OF ELECTRIC LOAD CHANGE
}

\author{
V.Z. Kochmarskii, V.O. Melnyk \\ National University of Water and Environmental Engineering, \\ Physical and technological laboratory of water systems. \\ Rivne, v.z.kochmarskii@ nuwm.edu.ua
}

The rate of solid calcium carbonate (Dve) formation in circulating water $(C W)$ of circulating cooling systems (CCS) of power plants with cooler towers and the stability index of such water at changing electric load is analyzed. The relationship between streams of CCS, namely, feeding, evaporation and blow, which exist under the condition of constant CCS water volume and dependence of evaporation flow upon units load are the basis of analysis. Such dependence is based on the fact that the main channel of heat dissipation after steam turbine units is evaporation in cooling towers. The general expression has been obtained in quasiequilibrium approximation that establishes the relation between Dve and $C W$ stability index. This dependence allows calculating $\mathrm{CW}$ stability degree for any models of $\mathrm{CaCO}_{3}$ formation kinetics and to obtain corresponding Dve value. It has been shown that the rate of solid $\mathrm{CaCO}_{3}$ formation is directly proportional to electrical load of power plant, $\mathrm{Ca}^{2+}$ ion concentration in feed water and fraction of used heat dissipated by evaporation, antiproportional to stability index, inverse to CCS water volume and the average efficiency of power plant.

Key words: circulating water, stability index, solid calcium carbonate, formation rate; electric load; evaporation flow.

Circulating cooling systems (CCS) of power plants predominately work in a regime which is optimized for stationary temperature of cooling water in order to ensure acceptable vacuum in turbine condensers (TC) at nominal electric load and simultaneously avoid condensate overcooling. Cooling, especially in summer, is achieved due to cooling water $(\mathrm{CW})$ evaporation ensuring lower temperature of cooling water by $5-8^{\circ} \mathrm{C}$ than that one after turbine condenser. In winter cooling is achieved equally by convection and evaporation, however, sometimes it is necessary to apply measures to maintain cooling water temperature at the level that does not lead to condensate depression [1-3]. It is clear that CCS should dissipate some fraction of heat into the environment which cannot be converted into work under the given thermodynamic conditions. This anergy fraction of steam enthalpy supplied to the steam power unit may be estimated by energy balance of power plant

$$
\sum\left(1-\eta_{i}\right) \cdot D^{o}{ }_{i} \cdot h_{i}^{o}=\sum\left(1-\eta_{i}\right) \cdot \eta^{-1} \cdot N_{i}=c_{w} \cdot \sum G_{j} \cdot \Delta t_{c w, j}
$$

sum of $\mathbf{i}$ is maintained by the number of unit $\mathbf{m} ; \mathrm{D}^{\mathrm{o}}{ }_{\mathrm{i}}, \mathrm{h}^{\mathrm{o}}{ }_{\mathrm{i}}, \eta_{\mathrm{i}}, \mathrm{Ne}_{\mathrm{i}}-$ steam, $\mathrm{kg} / \mathrm{s}$, consumption that is supplied to i power unit; fresh steam enthalpy, gross efficiency and electric load of the 
corresponding unit; $\mathrm{G}_{\mathrm{j}}, \mathrm{c}_{\mathrm{w}}, \Delta \mathrm{t}_{\mathrm{cw}, \mathrm{j}}$ - respectively, cooling water consumption through $\mathbf{j}$ condenser, water thermal capacity and temperature drop at $\mathbf{j}$-condenser.

Equation (1) allows calculating circulating water consumption necessary to ensure optimal operation of power plant and cooling capacity of coolers.

In view of the fact that in Ukraine there is no gas-turbine superstructure at power plants the function of generation regulation is exercised by heat power plants and sometimes nuclear power plants. Thus, power stations often operate in the regimes far from nominal; therefore the analysis of dependence of CCS operation regimes at changing electric load is a topical task.

From equation (1) we can see that at changing load of power plant units $\mathrm{Ne}_{\mathrm{i}}$ or their operation number there is the need to change the number of turbine condensers switched on, consumption of cooling water through separate TC or temperature drop at $\mathbf{j}$ turbine condenser. Regulation of cooling water supply at changing the number of operating units is achieved by switching off/on corresponding circulating pumps or changing their supply.

As it was already mentioned, in summer the main amount of steam heat, approximately ( 80 $-85 \%$ ), is removed from CCS by evaporation. This fact is expressed by the equation of energy balance dissipating by evaporated water,

$$
\mathrm{K}_{\mathrm{ev}} \cdot \sum\left(1-\eta_{\mathrm{i}}\right) \cdot \eta^{-1} \mathrm{i} \cdot \mathrm{Ne}_{\mathrm{i}}=\mathrm{G}_{\mathrm{ev}} \cdot \rho_{\mathrm{w}} \cdot \mathrm{r}_{\mathrm{w}}
$$

$\mathrm{K}_{\mathrm{ev}}$ - is the coefficient equal to heat fraction that is removed by evaporated water that depends on circulating water temperature and external conditions; $\mathrm{G}_{\mathrm{ev}}, \rho_{\mathrm{W}}, \mathrm{r}_{\mathrm{W}}$ - respectively, water consumption for evaporation, water density and heat capacity of evaporation at $\mathrm{CW}$ temperature.

Using (2) let us determine the $\mathrm{CW}$ consumption for evaporation necessary for plant operation.

$$
\mathrm{G}_{\mathrm{ev}}=\frac{\mathrm{K}_{\mathrm{ev}} \cdot \sum\left(1 / \eta_{\mathrm{i}}-1\right) \cdot \mathrm{Ne}_{\mathrm{i}}}{\rho_{\mathrm{w}} \cdot \mathrm{r}_{\mathrm{w}}}=\mathrm{K}_{\mathrm{ev}} \cdot \mathrm{A}(\eta) \cdot \mathrm{Ne}, \eta=\mathrm{m} / \sum \frac{1}{\eta_{\mathrm{i}}},
$$

$\eta$ - power plant average efficiency; Ne - general electric load of the plant, MW, the A( $\eta)$ coefficient content, $\mathrm{m}^{3} / \mathrm{MJ}$, follows from (3).

We can see that the change of electric load leads to proportional change of water consumption for evaporation and this, in turn, changes the CCS regime of operation since to compensate evaporation and maintain constant CCS water volume $\mathrm{V}, \mathrm{m}^{3}$, the feed water of $\mathrm{G}_{\mathrm{f}}$, $\mathrm{m}^{3} / \mathrm{s}$, consumption should be supplied into the system. Since evaporation leads to salts concentration (increase) to maintain the concentration degree $\mathbf{k}$ at the acceptable level the blow down it applied, its consumption can be denoted as $\mathrm{G}_{\mathrm{e}}$.

In case of constant CCS water volume $V, \mathrm{G}_{\mathrm{ev}}, \mathrm{G}_{\mathrm{f}}$ and $\mathrm{G}_{\mathrm{e}}$ values are linked together by the relationships [4-8],

$$
\mathrm{G}_{\mathrm{f}}=\mathrm{G}_{\mathrm{ev}}+\mathrm{G}_{\mathrm{e}} ; \varphi=\frac{\mathrm{G}_{\mathrm{f}}}{\mathrm{G}_{\mathrm{f}}-\mathrm{G}_{\mathrm{ev}}}=\frac{\mathrm{G}_{\mathrm{f}}}{\mathrm{G}_{\mathrm{e}}} ; \quad \mathrm{G}_{\mathrm{e}}=\frac{1}{\varphi-1} \mathrm{G}_{\mathrm{ev}} ; \mathrm{G}_{\mathrm{ev}}=\frac{\varphi-1}{\varphi} \mathrm{G}_{\mathrm{f}} ;
$$


,where $\mathrm{G}_{\mathrm{e}}$ - all flows consumption that remove salts from CCS including uncontrolled blow (filtration, drop-away); $\boldsymbol{\varphi}$ - dynamic CCS factor, its physical content becomes clear if tracers concentration (soluble salts, e.g. chlorides) reaches equilibrium (under the condition $t \rightarrow \infty$ ). Actually, in this case $\boldsymbol{\varphi}$ becomes equal to the coefficient of tracer's concentration $[6,9]$,

$$
\mathrm{dC}_{\mathrm{tr}} / \mathrm{dt} \rightarrow 0 \text { and we obtain } \varphi_{\infty} \rightarrow \frac{\mathrm{C}_{\mathrm{tr} \infty}}{\mathrm{C}_{\mathrm{tr} 0}}=\mathrm{k}
$$

Comparing (3) to the third formula (4), coefficient $\mathrm{K}_{\mathrm{ev}}$ can be defined and, thus, closed equation concerning $\mathrm{G}_{\mathrm{ev}}$ can be obtained.

Earlier, [in 5,7] we obtained the dynamic equation for the main component of low temperature $\mathrm{CaCO}_{3}$ deposits - active $\mathrm{Ca}^{2+}$ ion concentration in $\mathrm{CW}$. Let us denote it as $\mathrm{C}$ a, gion $/ \mathrm{m}^{3}$,

$$
\frac{\mathrm{dC}_{\mathrm{Ca}}}{\mathrm{dt}}=\frac{1}{\mathrm{~T}_{\mathrm{e}}} \cdot\left(\varphi \cdot \mathrm{C}_{\mathrm{Ca} 0}-\mathrm{C}_{\mathrm{Ca}}\right)-\frac{\mathrm{dC}_{\mathrm{Ca}_{\mathrm{SS}}}}{\mathrm{dt}} ; \quad \mathrm{T}_{\mathrm{e}}=\frac{\mathrm{V}}{\mathrm{G}_{\mathrm{e}}}
$$

$\mathrm{C}_{\text {Cass }}$ - molar concentration of solid $\mathrm{CaCO}_{3}$ precipitated from cooling water $(\mathrm{CW}), \mathrm{g}-\mathrm{mol} / \mathrm{m}^{3}$; $\mathrm{C}_{\mathrm{Ca} 0}$ - active $\mathrm{Ca}^{2+}$ ion concentration in feed water; V- CCS water volume, $\mathrm{m}^{3} ; \mathrm{T}_{\mathrm{e}}-$ time of CCS removal by blow.

In quasiequilibrium approximation $\left(\mathrm{t} \gg \mathrm{T}_{\mathrm{e}}\right)$, see details in [8], we can assume that $\mathrm{dC}_{\mathrm{Ca}} / \mathrm{dt} \rightarrow 0$ besides using the definition of stability index of circulating water $[7,11,12]$,

$$
\mathrm{I}_{\mathrm{st}}=\mathrm{C}_{\mathrm{Ca}} / \varphi \cdot \mathrm{C}_{\mathrm{Ca} 0}
$$

that is determined by operational data for any CCS with no difficulties, expression (6), taking into account (3) can be changed to the expression

$$
\frac{\mathrm{dC}_{\mathrm{Ca}_{\mathrm{ss}}}}{\mathrm{dt}}=\frac{\mathrm{C}_{\mathrm{Ca} 0}}{\mathrm{~T}_{\mathrm{f}}} \cdot\left(1-\mathrm{I}_{\mathrm{st}}\right)=\frac{\mathrm{G}_{\mathrm{f}} \cdot \mathrm{C}_{\mathrm{Ca} 0}}{\mathrm{~V}} \cdot\left(1-\mathrm{I}_{\mathrm{st}}\right), \mathrm{T}_{\mathrm{f}}=\frac{\mathrm{V}}{\mathrm{G}_{\mathrm{f}}},
$$

$\mathrm{T}_{\mathrm{f}}$ - time of filling of volume $\mathrm{V}$ with feed water.

Defining the rate of solid $\mathrm{CaCO}_{3}$ formation

$$
\frac{\mathrm{dC}_{\mathrm{Ca}_{\mathrm{ss}}}}{\mathrm{dt}}=\mathrm{Dve}
$$

we can present (8) as 


$$
\operatorname{Dve}\left(\mathrm{Ne}, \varphi, \eta, \mathrm{K}_{\mathrm{ev}}, \mathrm{C}_{\mathrm{Ca} 0}, \mathrm{Ist}\right)=\frac{\varphi \cdot \mathrm{C}_{\mathrm{Ca} 0} \cdot \mathrm{A}(\eta) \cdot \mathrm{K}_{\mathrm{ev}} \cdot \mathrm{Ne}}{(\varphi-1) \cdot \mathrm{V}} \cdot\left[1-\mathrm{I}_{\mathrm{st}}\left(\mathrm{C}_{\mathrm{Ca}}, \mathrm{C}_{\mathrm{Ca} 0}, \varphi\right)\right]
$$

From the expression (8a) it follows that $\mathrm{CaCO}_{3 s s}$, Dve formation rate is:

- directly proportional to Ne electric load of power plant;

- $\mathrm{Ca}^{2+}$ ions concentration in feed water $\mathrm{C}_{\mathrm{Ca} 0}$ and in $\mathrm{CW} \mathrm{C}_{\mathrm{Ca}}$;

- $\quad$ antiproportional to $\mathrm{I}_{\mathrm{st}}$ stability index;

- inversive to CCS V water volume;

- directly proportional to $\varphi$ at $\varphi<5$, but at $\varphi>5$ actually does not depend on $\varphi$;

- proportional to $\mathrm{K}_{\mathrm{ev}}$ coefficient and inversive, see expression (3), to average efficiency which is determined by the procedure (3).

Thus, to minimize solid $\mathrm{CaCO}_{3}$ formation in CCS it is necessary to achieve maximum $\mathrm{CW}$ stability, for example, by using inhibitors of deposits; to minimize calcium concentration in feed water and to operate the units at low evaporation coefficients $\mathrm{K}_{\mathrm{ev}}$ that is realized in cold season. It is also important to maintain maximum efficiency of the plant. We also draw your attention to the fact that CCS with large water volume are characterized by lower rate of solid $\mathrm{CaCO}_{3}$ formation than that one with lower volume under the similar conditions, that is plants with cooling pools of the so-called minimization of carbonate pollution are characterized by lower rate of solid $\mathrm{CaCO}_{3}$ formation in comparison to others.

From the expression (9) we can see that in cold season when electric load $\mathrm{Ne}$ of the power plant is increased the evaporation $\mathrm{K}_{\mathrm{ev}}$ coefficient is decreased, so the action of these two factors compensate each other.

Note that an important condition for designing new power units and technically competent operation of existing ones is the forecast and operation information on CW stability. It is easy to calculate CW stability for existing power plant by (7), see also [12].

For the designed CCS this information can be obtained by calculation on the data basis of physical and chemical properties of the local power supply. In this case the stability index of circulating water may be determined by $(8)$,

$$
\mathrm{I}_{\mathrm{st}}=1-\frac{\mathrm{V}}{\mathrm{G}_{\mathrm{f}} \cdot \mathrm{C}_{\mathrm{Ca} 0}} \cdot \frac{\mathrm{dC}_{\mathrm{Ca}_{\mathrm{ss}}}}{\mathrm{dt}}
$$

The value of the rate of solid $\mathrm{CaCO}_{3}$ formation in (9) is determined experimentally or by using well-known laws, see, for example, [8] and in such a way an expected CW stability is calculated.

In general case taking into account the data of [9] we can consider with sufficient accuracy that the law of the rate of solid $\mathrm{CaCO}_{3}$ formation depends on the limited number of $\mathrm{CW}$ parameters: $\mathrm{C}_{\mathrm{Ca}}, \mathrm{C}_{\mathrm{CO} 2}, \mathrm{pH}$ and $\mathrm{t}$, we defined it in general case as $\mathrm{F}\left(\mathrm{C}_{\mathrm{Ca}}, \mathrm{C}_{\mathrm{CO} 2}, \mathrm{pH}, \mathrm{t}\right)$ and obtain generalized formula for $\mathrm{I}_{\mathrm{st}}$ calculation,

$$
\mathrm{I}_{\mathrm{st}}\left(\mathrm{C}_{\mathrm{Ca} 0}, \mathrm{C}_{\mathrm{Ca}}, \mathrm{C}_{\mathrm{CO} 2}, \mathrm{pH}, \mathrm{t}\right)=1-\frac{\mathrm{V}}{\mathrm{G}_{\mathrm{f}} \cdot \mathrm{C}_{\mathrm{Ca} 0}} \cdot \mathrm{F}\left(\mathrm{C}_{\mathrm{Ca}}, \mathrm{C}_{\mathrm{CO} 2}, \mathrm{pH}, \mathrm{t}\right) \cdot
$$


Concretize (10) using, for example, the law [8, 13],

$$
\frac{\mathrm{dC}_{\mathrm{Ca}}}{\mathrm{dt}}=\mathrm{K} \cdot \mathrm{C}_{\mathrm{Ca}} \cdot \mathrm{C}_{\mathrm{HCO} 3}=\mathrm{K} \cdot \mathrm{K}_{1} \cdot 10^{-\mathrm{pH}} \cdot \mathrm{C}_{\mathrm{Ca}} \cdot \mathrm{C}_{\mathrm{CO} 2},
$$

$\mathrm{K}$ - kinetic constant $\mathrm{CaCO}_{3}$ formation determined by special research for water of projected CCS; $\mathrm{K}_{1}-\mathrm{CO}_{2}$ hydration constant.

Substituting (11) in (10) we obtain,

$$
\begin{aligned}
& \mathrm{I}_{\mathrm{st}}=1-\frac{\mathrm{V}}{\mathrm{G}_{\mathrm{f}} \cdot \mathrm{C}_{\mathrm{Ca} 0}} \cdot \mathrm{K} \cdot \mathrm{C}_{\mathrm{CaOo}} \cdot \mathrm{C}_{\mathrm{HCO} 3 \mathrm{oo}}= \\
& =\frac{1}{1+\varphi \cdot \mathrm{T}_{\mathrm{f}} \cdot \mathrm{K} \cdot \mathrm{C}_{\mathrm{HCO} 3 \mathrm{oo}}}=\frac{1}{1+\mathrm{T}_{\mathrm{e}} \cdot \mathrm{K} \cdot \mathrm{C}_{\mathrm{HCO} 3 \mathrm{oo}}}
\end{aligned}
$$

$\mathrm{C}_{\mathrm{Ca} 00}, \mathrm{C}_{\mathrm{HCO} 300}$ - ions concentration in cooling water in quasiequilibrium state; $\varphi$ - projected degree of salts concentration; $\mathrm{T}_{\mathrm{f}}$ - time of filling of CCS water volume with feed water.

Note that the degree of $\mathrm{CW}$ stability at the selected law of solid $\mathrm{CaCO}_{3}$ formation does not depend on calcium ions concentration. Actually it is not so, since $\mathrm{C}_{\mathrm{HCO} \text { oo }}$ and $\mathrm{C}_{\mathrm{Caoo}}$ concentrations are linked with each other, see [13].

However, the expression (12) indicates the ways to achieve maximum CW stability by means available, namely, work at low $\varphi$ which is achieved by regulating feed and blow consumption; changing $\mathrm{T}_{\mathrm{f}}$ or $\mathrm{T}_{\mathrm{e}}$ using the same means; reducing $\mathrm{K}$ constant using solid $\mathrm{CaCO}_{3}$ formation inhibitors and $\mathrm{C}_{\mathrm{HCO} 3}$ - applying acidification. To achieve clear dependence of $\mathrm{I}_{\mathrm{st}}$ upon units load for the adopted law of solid $\mathrm{CaCO}_{3}$ formation rate it is quite enough to use the expression (3) and the relationship (4).

$$
\mathrm{I}_{\mathrm{st}}\left(\mathrm{Ne}, \varphi, \eta, \mathrm{K}, \mathrm{K}_{\mathrm{ev}}, \mathrm{C}_{\mathrm{HCO} 30 \mathrm{o}}\right)=\frac{1}{1+(\varphi-1) \cdot \frac{\mathrm{K} \cdot \mathrm{V} \cdot \mathrm{C}_{\mathrm{HCO} 30 \mathrm{o}}}{\mathrm{K}_{\mathrm{ev}} \cdot \mathrm{A}(\eta) \cdot \mathrm{Ne}}}
$$

As a result we obtain where we can see that units load and their work at high outdoor temperatures $\left(\mathrm{A}(\eta)\right.$ increase) promotes $\mathrm{I}_{\text {st }}$ growth, on the contrary, in cold weather when $\mathrm{K}_{\mathrm{ev}} \cdot \mathrm{A}(\eta) \cdot \mathrm{Ne}$ is decreased $\mathrm{CW}$ stability is reduced.

Let us use the expressions obtained to analyze the operation of a specific heat power plant [14] where partial softening of feed water and CCS with cooling towers are used. 


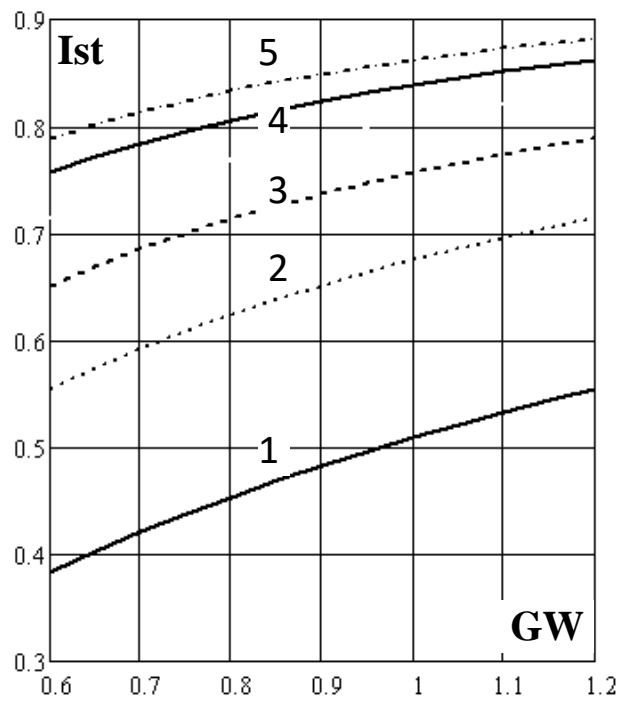

Fig. 1. Dependence of stability index on electric load. Curves $1 \ldots .5$ correspond to kinetic constant value $\mathrm{K}(1,1 ; 0,55 ; 0,37$; $0,28 ; 0,22) \cdot 10^{-4} \mathrm{~m}^{3} / \mathrm{g}$-ion $/ \mathrm{h}$. Meanings of other parameters are given above.

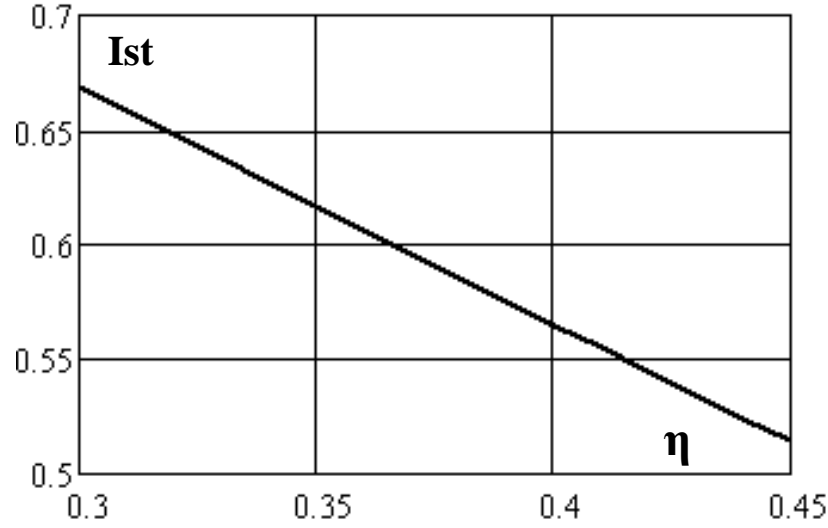

Fig. 2. Dependence of stability index on efficiency. Values of other parameters are unchangeable.

Let us accept: $\mathrm{Ne}=4 \times 300 \mathrm{MW} ; \varphi_{\infty}=3.5 ; \mathrm{V}=240 \cdot 10^{3} \mathrm{~m}^{3} ; \mathrm{K}=1.1 \cdot 10^{-4} \mathrm{~m}^{3} /(\mathrm{g}$-ion $) \cdot \mathrm{h} . ; \mathrm{C}_{\mathrm{Ca} 0}$ $=0.7($ g-ion $) / \mathrm{m}^{3}, \mathrm{C}_{\text {HCO3oo }}=7($ g-ion $) / \mathrm{m}^{3}, \mathrm{~A}(\eta)=6 \cdot 10^{-4}$ $\mathrm{m}^{3} / \mathrm{MJ}$

Based on this data we obtain from (8) and (13) the dependence of $I_{\text {st }}$ on $\mathrm{Ne}$, see fig. 1 for different meanings of kinetic $\mathrm{K}$ constant. We can see that decrease of $\mathrm{K}$ (inhibitors use) increases $\mathrm{CW}$ stability, on the contrary, its growth reduces.

As we can see from (13) the similar $\mathrm{I}_{\mathrm{st}}$ behavior corresponds to $\varphi, \quad \mathrm{V}$ and $\mathrm{C}_{\mathrm{HCO} \text { oo }}$ changes. Dependence of $\mathrm{I}_{\text {st }}$ on gross efficiency of the plant is shown in fig 2. The reduction of $\mathrm{I}_{\text {st }}$ at the efficiency growth is due to $A(\eta)$ dependence, see (3) and (13). In practice it is connected with the reduction of the degree of salt concentration due to reduction of consumption for evaporation, see (7) and (12). Thus, units operation at low efficiency favors $\mathrm{CW}$ stability.

The value of solid $\mathrm{CaCO}_{3}$ formation rate is determined on the basis of the law (11) by using quasiequilibrium meaning for $\mathrm{Ca}^{2+}$ which is obtained from (6) at $\mathrm{dC}_{\mathrm{Ca}} / \mathrm{dt} \rightarrow 0$ and taking (11) into account.

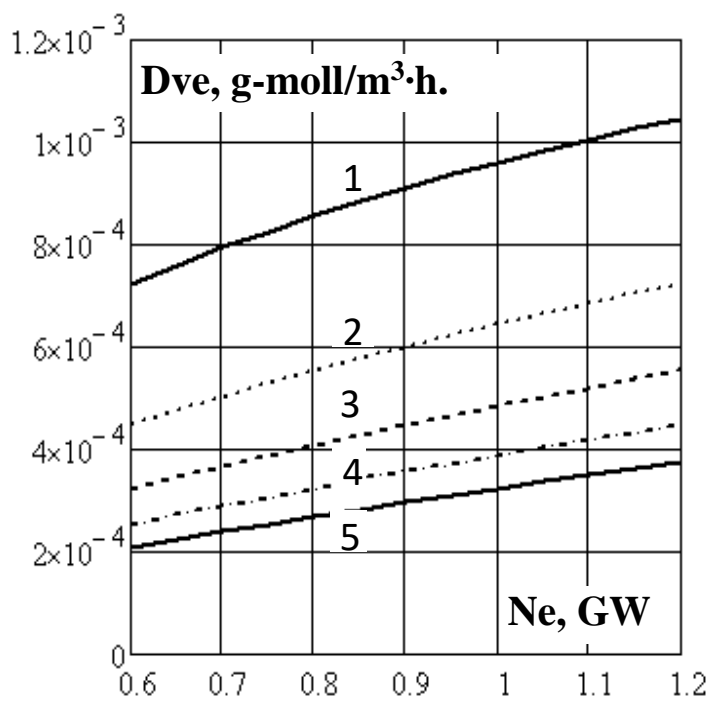

Fig. 3. Dependence of solid $\mathrm{CaCO}_{3}$ formation rate on electric load. Curves $1 \ldots 5$ correspond to kinetic constant value $\mathrm{K}=$ $(1,1 ; 0,55 ; 0,37 ; 0,28 ; 0,22) 10^{-4} \mathrm{~m}^{3} / \mathrm{g}-$ ion $/ \mathrm{h}$. Meanings of other parameters are given above.

The result is presented in the expression 


$$
\operatorname{Dve}\left(\mathrm{Ne}, \varphi, \eta, \mathrm{K}, \mathrm{K}_{\mathrm{ev}}, \mathrm{C}_{\mathrm{Cao}}, \mathrm{C}_{\mathrm{HCO} 3 \mathrm{oo}}\right)=\frac{\varphi \cdot \mathrm{K} \cdot \mathrm{C}_{\mathrm{Cao}} \cdot \mathrm{C}_{\mathrm{HCO} 300}}{1+(\varphi-1) \cdot \frac{\mathrm{K} \cdot \mathrm{V} \cdot \mathrm{C}_{\mathrm{HCO} 3 o 0}}{\mathrm{~K}_{\mathrm{ev}} \cdot \mathrm{A}(\eta) \cdot \mathrm{Ne}}}
$$

Calculation by (14) formula with the same parameters as in fig. 1, is shown in fig. 3 . Maximum solid $\mathrm{CaCO}_{3}$ formation rate corresponds to maximum kinetic $\mathrm{K}$ coefficient, fig. 3 curve 1. Besides, units operation with maximum load favors the increase of solid $\mathrm{CaCO}_{3}$ formation rate This growth is of the same nature both for stability index, see expression (13) and solid $\mathrm{CaCO}_{3}$ formation rate, see (14). It is also evident that feed water softening and $\mathrm{CW}$ acidification reduce Dve.

Dependence of solid $\mathrm{CaCO}_{3}$ formation rate on gross efficiency is shown in fig. 4 . As in the case with stability index this value is reduced at plant efficiency growth. Efficiency growth is accompanied by the reduction of water consumption for evaporation. This in turn reduces water exchange in CCS and, consequently, salts supply for CCS.

Dependence of solid $\mathrm{CaCO}_{3}$ formation rate on the degree of $\boldsymbol{\varphi}$ concentration (increase) is shown in fig. 5.

Dve value is increased at $\boldsymbol{\varphi}$ and electric load growth of the plant. Thus, the increase of solid $\mathrm{CaCO}_{3}$ formation rate at units operation with maximum load and the degree of salt concentration (small blow) should be accompanied by the use of inhibitors, means of feed water softening and CW acidification.

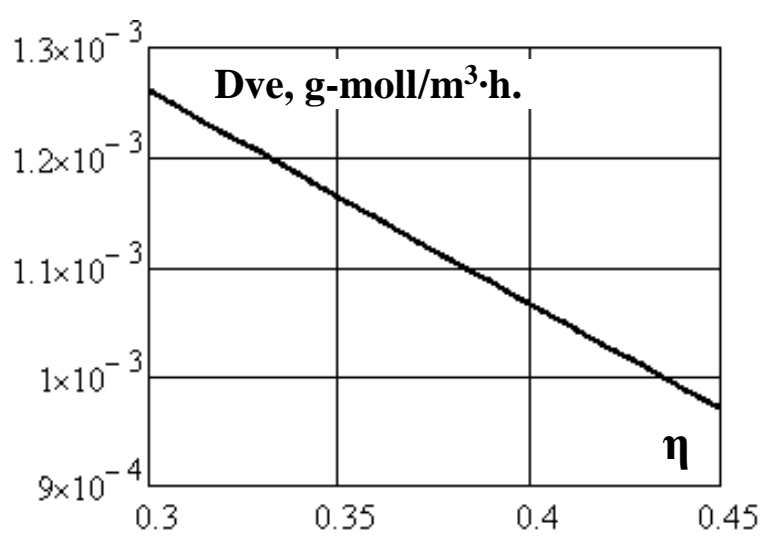

Fig. 4. Dependence of solid $\mathrm{CaCO}_{3}$ precipitation rate on plant gross efficiency. Other parameters are unchangeable.

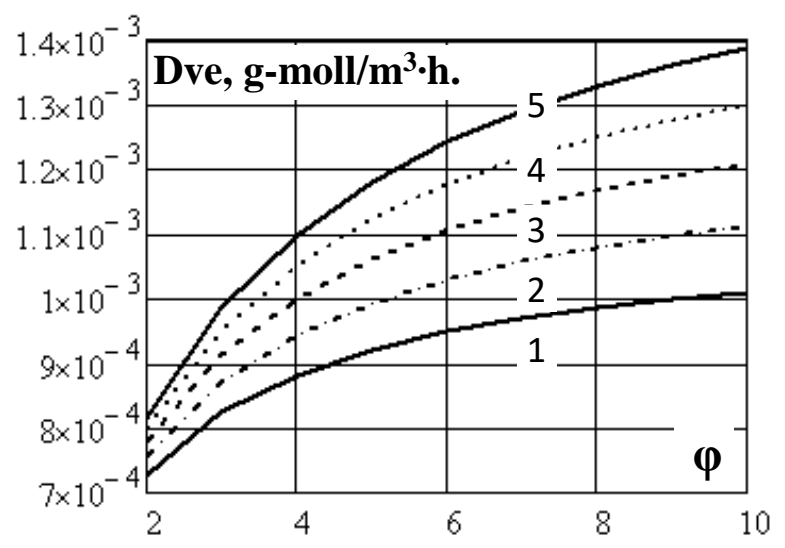

Fig. 5. Dependence of solid $\mathrm{CaCO}_{3}$ formation rate on the degree of salts concentration. Load Ne $(0,8 ; 0,9 ; 1,0 ; 1,1$; 1,2) GW corresponds to cures $1 \ldots 5$. Other parameters are unchangeable.

Note that conclusions from expressions (13) and (14) qualitatively coincide with data [15], however, obtained here formulas (13) and (14) give the opportunity for agreed calculation of acids and inhibitors doses, as well as the degree of feed water softening with electric load of units. Their uses allow carrying out technical and economic optimization of the process of $\mathrm{CaCO}_{3}$ formation minimization and CCS operation regime. That is, to create the prerequisites for automation of the process of solid $\mathrm{CaCO}_{3}$ formation control under the dynamic conditions of power units operation. 


\section{Summary}

1. Operation regime of CCS with cooling towers should be agreed to electric load of plant units since it changes circulating water consumption for evaporation and all other flows at constant CCS water volume.

2. CW stability index is increased at electric load and environmental temperature growth and is decreased at gross efficiency growth.

3. Maximum CW stability for the given CCS may be achieved by the following means: operating at low $\boldsymbol{\varphi}$ that is achieved by regulation of feed and blow consumption, reducing kinetic constant $\mathrm{K}$ in the law of $\mathrm{CaCO}_{3}$ formation by using inhibitors and reducing bicarbonate $\mathrm{C}_{\mathrm{HCO}}$ concentration applying acidification. Formulas (13) and (14) allow calculating necessary doses and developing procedures to achieve projected stability and control solid $\mathrm{CaCO}_{3}$ formation rate.

4. To minimize solid $\mathrm{CaCO}_{3}$ formation at $\mathrm{CCS}$ it is necessary to achieve maximum $\mathrm{CW}$ stability; minimize calcium concentration in feed water and to operate units at low evaporation $\mathrm{K}_{\mathrm{ev}}$ coefficients that is exercised in cold season. It is also important to maintain maximum plant efficiency.

5. Dve value is increased at the growth of $\boldsymbol{\varphi}$ and plant electric load. Thus, the increase of $\mathrm{CaCO}_{3}$ formation rate at power units operation with maximum load and degree of salt concentration (small blowing) should be accompanied by using of inhibitors, means of softening of feed water and $\mathrm{CW}$ acidification.

6. The procedure suggested allows qualitative forecasting of $\mathrm{CW}$ stability at designing new power units on the data basis of physical and technical water properties of local water source and justifying the choice of optimal measures to minimize the rate of solid $\mathrm{CaCO}_{3}$ formation.

7. For safe forecast of $\mathrm{CW}$ stability of new plants it is necessary to do experimental research for identifying the law of solid $\mathrm{CaCO}_{3}$ formation or determining kinetic coefficient $\mathrm{K}$ by using water that models $\mathrm{CW}$ for projected CCS.

8. Expressions (13) and (14) may be accepted as the basis for technical and economic optimization of the process of deposits minimization and the CCS operation regime that may be changed as well as for developing mathematical model of automation of deposits control under such conditions.

\section{ВИДІЛЕННЯ ТВЕРДОГО СаСОз У ВОДАХ ОБОРОТНИХ СИСТЕМ ОХОЛОДЖЕННЯ ЕЛЕКТРОСТАНЦЙ В УМОВАХ ЗМІННОГО ЕЛЕКТРИЧНОГО НАВАНТАЖЕННЯ}

\section{В. 3. Кочмарський, В. О. Мельник}

Національний університет водного господарства і природокористування, Фізико-технологічна лабораторія водних систем. Рівне, v.z.kochmarskii@nuwm.edu.ua

Аналізується швидкість виділення карбонату кальцію з оборотної води (OB) систем охолодження електростанцій з градирнями та ступінь стабільності таких вод при змінному електричному навантаженні. В основу аналізу покладено зв'язок між потоками оборотної системи охолодження (ОСО), зокрема підживлення, випаровування та продувки, який $є$ за умови сталого водного об'єму ОСО та залежність потоку випаровування від навантаження 
блоків. Ця залежність грунтується на тому, що основним каналом розсіювання тепла після паротурбінних установок $\epsilon$ випаровування води в градирнях. У квазірівноважному наближенні отримано загальний вираз, яким встановлюється зв'язок між швидкістю виділення карбонату кальцію та індексом стабільності ОВ. Ця залежність дозволяє розраховувати ступінь стабільності ОВ для будь-яких моделей кінетики виділення $\mathrm{CaCO}_{3}$ та отримувати відповідну величину швидкості виділення. Показано, що швидкість виділення $\mathrm{CaCO}_{3}$, прямо пропорційна електричному навантаженню електростанції; концентрації іонів $\mathrm{Ca}^{2+}$ у воді підживлення, та частці відпрацьованого тепла, що розсіюється випаровуванням; Досягнути максимальної стабільності ОВ для даної ОСО можна: роботою при малих ступенях концентрування солей, що забезпечується регулюванням витрат підживлення i продувки, використовуючи інгібітори, та зменшуючи концентрацію бікарбонатів підкисленням. Отримані в роботі вирази, дозволяють розрахувати необхідні дози та розробити процедури для досягнення заданої стабільності i контролювати швидкість виділення $\mathrm{CaCO}_{3}$. Запропонована в статті методика дозволяє при проектуванні нових енергоблоків (станцій) робити кількісний прогноз стабільності ОВ на підставі даних про якість води місцевого джерела живлення та обгрунтовувати вибір оптимальних заходів щодо мінімізації швидкості виділення $\mathrm{CaCO}_{3}$. Для надійного прогнозу стабільності $\mathrm{OB}$ нових станцій необхідні експериментальні дослідження для ідентифікації закону виділення $\mathrm{CaCO}_{3}$. Наведені в роботі вирази можуть також бути прийняті за основу при техніко-економічній оптимізації процесу мінімізації відкладень та режиму експлуатації ОСО для змінних режимів роботи станцій, а також при розробці матмоделей для автоматизації процесу контролю над відкладеннями за таких умов.

Ключові слова: оборотна вода; індекс стабільності; твердий карбонат кальцію; швидкість виділення; електричне навантаження; потік випаровування.

\section{ВЫДЕЛЕНИЯ ТВЕРДОГО САСОЗ В ВОДАХ ОБОРОТНЫХ СИСТЕМ ОХЛАЖДЕНИЯ ЭЛЕКТРОСТАНЦИЙ В УСЛОВИЯХ ПЕРЕМЕННОЙ ЭЛЕКТРИЧЕСКОЙ НАГРУЗКИ}

\section{В. 3. Кочмарский, В. А. Мельник}

Национальный университет водного хозяйства и природопользования. Физикотехнологическая лаборатория водных систем. Ровно, v.z.kochmarskii@nuwm.edu.ua

Исследуется скорость выделения твердого карбоната кальция Dve с оборотной воды (OB) оборотной систем охлаждения (ОСО) электростанций с градирнями и степень стабильности таких вод при переменной электрической нагрузке. Анализ основан на связи между потоками ОСО: подпитки, испарения и продувки, существующей при постоянном водном объеме ОСО и зависимости потока испарения от нагрузки блоков. Эта зависимость основана на том, что основным каналом рассеивания тепла после паротурбинных установок является испарение воды в градирнях. В квазиравновесном приближении получено общее выражение, которым устанавливается связь между Dve и индексом стабильности ОВ. Эта зависимость позволяет рассчитать степень стабильности ОВ для произвольных моделей кинетики выделения $\mathrm{CaCO}_{3}$ и получить соответствующую величину Dve. Показано, что скорость выделения $\mathrm{CaCO}_{3 т в}$, прямо пропорциональна электрической нагрузке электростанции; концентрации ионов $\mathrm{Ca}^{2+}$ в воде подпитки, и части отработанного тепла, что рассеивается испарением; антипропорциональна индексу стабильности; обратно пропорциональна водному объему ОСО и среднему КПД станции.

Ключевые слова: оборотная вода; индекс стабильности; твердый карбонат кальция; скорость выделения; электрическая нагрузка; поток испарения. 


\section{References}

1. L.S. Sterman, V.M. Lavygin, S.G. Grishin. Heat and nuclear power plants. - Moscow: MEI Publishing house. - 2000. - P. 408.

2. M.V. Topolnytckyi. Nuclear power plants. - Lviv: Publishing house "Beskid Bit". - 2005. - P. 523.

3. A.G. Laptiev, I.A. Vedgaieva. Design and calculation of industrial cooling towers. Kazan State Power Engineering University. - Kazan. - 2004. - P. 175.

4. V.Z. Kochmarskii. Kinetic model of calcium carbonate water system. // Mat. of 2nd scientific and technical conference of the teaching staff of Ukrainian State Academy of Water Management. - Rivne. - 1996. - V. 3. - Pp. 4-6.

5. V.Z. Kochmarskii. Kinetic model of carbonate system in terms of circulating water supply. // Bulletin of Ukrainian State Academy of Water Management. - Rivne. - 1998. - V.1. - - Pp. 236243.

6. V.Z. Kochmarskii, V.R. Gayevskii. Analysis of tracer's dynamics in circulating cooling systems. // Bulletin of Land Reclamation and Hydrotechnical Construction. - Rivne. - 2007. V. 32. - Pp. 166-173.

7. V.Z. Kochmarskii, V.R. Gayevskii, O.V. Kochmarskii. Dynamics of precipitating agents in circulating cooling systems. // Bulletin of National University of Water Management. - Rivne. 2008. - V.1(41). - Pp. 258-268.

8. V.Z. Kochmarskii. Kinetics of $\mathrm{CaCO}_{3}$ crystallization. Dynamic model. //Water and Water technologies. Scientific and technical news. - Kyiv. - 2010. - №2. - Pp. 14-27.

9. V.Z. Kochmarskii. Kinetics of $\mathrm{CaCO}_{3}$ crystallization. Quasiequilibrium model. //Water and Water technologies. Scientific and technical news. - Kyiv. - 2010. - №1 - - Pp. 12-21.

10. D.I. Kucherenko, D.I. Gladkov. Circulating water supply. (Systems of water cooling). Moscow: - Strojizdat. - 1980. - P. 169.

11. V.Z. Kochmarskii, O.V. Kochmarskii. Deposits in circulating systems of heat power plants. // Heat engineering. New challenges of the time. Bulletin of scientific papers. Editors: P. Omelianovskyi, V. Mysak. - Lviv: - Ukrainian technologies. - 2009. - Pp. 535-546.

12. Patent UA114060. The way to determine the stability index of circulating water of technical water supply systems concerning solid $\mathrm{CaCO}_{3}$ formation. Kochmarskii V.Z., Kochmarskii O.V. - Published in 2017.

13. V.Z. Kochmarskii, V.R. Gayevskii, N.L. Tyshko. Calcium carbonate crystallization from hydrocarbonate solutions. // Ukrainian journal of physics. - 2017. - V. 62. - №5. - Pp. 382-390.

14. V.Z. Kochmarskii, O.V. Kochmarskii, I.P. Fesenko. Dynamics of deposits inhibitor in circulating water at Zujev heat power plant. // Power engineering and electrification. - 2014. - № 11. - Pp. 12-16.

15. V.I. Terentjev, C.V. Karavan. The choice of optimal water-chemical regime of operation of circulating water cooling systems with cooling towers. Power saving and water treatment. 2007. - № 3. - Pp. 20-22. 